圧電体のエネルギー解放率*

南秉 群*1, 渡 邊 勝 彦*1

\title{
Energy Release Rate for Piezoelectric Body
}

\author{
Byeung-Gun $\mathrm{NAM}^{* 2}$ and Katsuhiko WATANABE \\ ${ }^{* 2}$ Institute of Industrial Science, The University of Tokyo, \\ 4-6-1 Komaba, Meguro-ku, Tokyo, 153-8505 Japan
}

\begin{abstract}
Crack Energy Density (CED), that is, the parameter that enables a unified description of crack behavior without any restriction on constitutive equation and its applicability had been shown for ordinary materials was extended to piezoelectric body in the previous paper. Taking into consideration this new knowledge about CED, in this paper, the energy release rate for piezoelectric body is discussed and the fundamental matters such as the relations of energy release rate with CED, its derivatives and $J$ integral are elicited. A crack is modeled by a notch with a sufficiently small root radius and a sharp crack is treated as the limit when root radius approaches zero. Energy release rate is derived through two different procedures and it is shown that energy release rate is equal to the electric enthalpy area density, that is, the difference between mechanical CED and complementary electrical CED. Moreover, how mechanical and electrical contributions of energy release rate are given is also discussed.
\end{abstract}

Key Words : Fracture, Piezoelectric Material, Energy Release Rate, Crack Energy Density (CED), Path Independent Integral

\section{1. 腥 言}

この十数年, 圧電材料の破壊力学に関する研究が活 発に行われている(1)-(12). しかし, 現在に至るも, き裂パラ メータとして何を用いるかといった基本的問題も含め, 多くの同意を得る形での方向性が打ち出せず, 方法論 についての模索が続いている. そこで著者らは先にここ の状況の一因に, 通常材料において, その導入によって 構成則によらず問題の統一的取り扱いが可能となるこ とが示されているき裂エネルギ一密度(Crack Energy Density, CED)の概念(13)-16の欠如があるのではないかと 考え, 圧電体に CED の概念を拡張導入し，その径路独 立積分表示等,圧電体 CED に関わる基本的な関係を導 いた(17). 本研究はその新たな知識を踏まえ, 圧電体にお けるエネルギ一解放率について論じるものである.

エネルギ一解放率は早くから圧電体に拡張され(1), 同じく圧電体に拡張された $J$ 積分(1)とともに破壊パ ラメータ候補の中心的扱いを受けてきている. そして これらは, 圧電体中の欠陷を電気的含有物(electrical inclusion)と見なす場合には欠陥表面での電気的エネル ギ一の寄与により両者は一致しなくなるといった議論 もあるが(10)(11), 基本となるき裂面での電気的不浸透性

\footnotetext{
* 原稿受付 2005 年 7 月 20 日.

*1 正員, 東京大学生産技術研究所( 153 - 1505 東京都目黑区 駒場 4-6-1)

E-mail : nam @ ced.iis.u-tokyo.ac.jp
}

条件 (impermeable condition) の下では, 通常の材料にお ける事実もあってか, 詳細な検討は必ずしも行われる ことなく, 両者は一致するものとして混然と用いられ ているようなところがある. 特に, エネルギ一解放率が 何故そのように与えられるに至るか心導出過程につい て明確に示している研究は見当らない!

こうしたことから, 本研究では, 基本となる不浸透性 条件の下での圧電体のエネルギ一解放率を，その定義 から出発して検討する．始めにエネルギ一解放率を論 じその意味を把握するにあたつて必要から有用となる, 先の研究で得られた CED およびそれに関連する諸量 についての事項(1)をまとめる. 続いてこれらを踏まえ， 圧電体のエネルギ一解放率がどのように与えられるか 導き, エネルギ一解放率と CED およびその関連量, さ らには $J$ 積分と呼ばれる量との関係等, エネルギ一解 放率に関わる基本的事項を明らかにする.

\section{2 圧電体における CED と関連諸量 $(17)$}

エネルギ一解放率は, 通常, 材料の可逆な挙動を前提 として論じられている.そこでここでは, エネルギ一解 放率との関係, 対応を考える立場から, 可逆な挙動を考 える場合における圧電体の CED およびその関連量に 関する事項をまとめる. 静的な場を考えており, 体積力 と体積電荷の存在は考えていない! また, き裂面では電 気的不浸透性条件を考えている. 


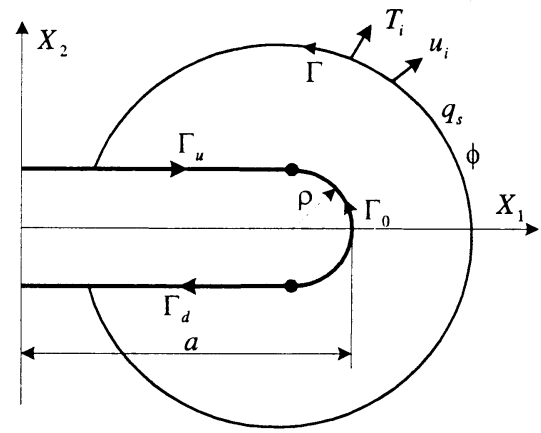

Fig. 1 Piezoelectric body with a notch

き裂を図 1 に示すような圧電連続体中の十分小さな 曲率半径 $\rho$ を有する切欠きでモデル化するものとし， 通常用いられる鋭いき裂モデルは $\rho \rightarrow 0$ の極限とし て位置づける. このとき, $\mathcal{E}$ を $\mathrm{CED}, \mathcal{E}^{M}, \mathcal{E}^{E}$ をそれぞ れその力学的奇与分, 電気的寄与分, すなわち力学的 CED,電気的 CED として, それらは

$$
\begin{aligned}
\mathcal{E} & =\int_{\Gamma_{0}} W d X_{2} \\
& =\int_{\Gamma}\left(W n_{1}-T_{i} u_{i, 1}-\phi q_{s, 1}\right) d \Gamma+\int_{\Gamma_{0}} \phi q_{s, 1} d \Gamma \\
\mathcal{E}^{M} & =\int_{\Gamma_{0}} W^{M} d X_{2} \\
& =\int_{\Gamma}\left(W^{M} n_{1}-T_{i} u_{i, 1}\right) d \Gamma-\int_{A} \int_{0}^{t}\left(\sigma_{i j, 1} d \varepsilon_{i j}-\varepsilon_{i j, 1} d \sigma_{i j}\right) d A
\end{aligned}
$$

$$
\begin{aligned}
\mathcal{E}^{E}=\int_{\Gamma_{0}} W^{E} d X_{2} & =\int_{\Gamma_{0}} \phi q_{s, 1} d \Gamma+\int_{\Gamma}\left(W^{E} n_{1}-\phi q_{s, 1}\right) d \Gamma \\
& -\int_{A} \int_{0}^{C}\left(E_{j, 1} d D_{j}-D_{j, 1} d E_{j}\right) d A
\end{aligned}
$$

によって与えられる量であり, また, $\mathcal{E}_{c}$ をコンプリメ ンタリーな $\mathrm{CED}, \mathcal{E}_{c}^{M}, \mathcal{E}_{c}^{E}$ を, それぞれ，その力学的寄. 与分,電気的寄与分として,これらの量は

$$
\begin{aligned}
& \mathcal{E}_{c}= \int_{\Gamma_{0}} W_{c} d X_{2}=\int_{\Gamma}\left(W_{c} n_{1}-u_{i} T_{i, 1}-q_{s} \phi_{, 1}\right) d \Gamma \\
&+\int_{\Gamma_{0}} u_{i} T_{i, 1} d \Gamma \\
& \mathcal{E}_{c}^{M}=\int_{\Gamma_{0}} W_{c}^{M} d X_{2}=\int_{\Gamma}\left(W_{c}^{M} n_{1}-u_{i} T_{i, 1}\right) d \Gamma+\int_{\Gamma_{0}} u_{i} T_{i, 1} d \Gamma \\
& \\
&+\int_{A} \int_{0}^{M}\left(\sigma_{i j, 1} d \varepsilon_{i j}-\varepsilon_{i j, 1} d \sigma_{i j}\right) d A
\end{aligned}
$$

$$
\begin{aligned}
\mathcal{E}_{c}^{E}=\int_{\Gamma_{0}} W_{c}^{E} d X_{2}= & \int_{\Gamma}\left(W_{c}^{E} n_{1}-q_{s} \phi_{, 1}\right) d \Gamma \\
& +\int_{A} \int_{0}^{T}\left(E_{j, 1} d D_{j}-D_{j, 1} d E_{j}\right) d A
\end{aligned}
$$

によって与えられる.ここで, $W, W^{M}, W^{E}$ は, それぞ れ

$$
\begin{aligned}
& W=W^{M}+W^{E} \\
& W^{M}=\int_{0}^{t} \sigma_{i j} d \varepsilon_{i j}, W^{E}=\int_{0}^{t} E_{i} d D_{i}
\end{aligned}
$$

で定義される抁張ひずみエネルギ一密度, その力学的 寄与分, 電気的寄与分, $W_{c}, W_{c}^{M}, W_{c}^{E}$ は,それぞれ

$$
\begin{aligned}
& W_{c}=W_{c}^{M}+W_{c}^{E} \\
& W_{c}^{W}=\int_{0}^{t} \varepsilon_{i j} d \sigma_{i j}, W_{c}^{E}=\int_{0}^{t} D_{i} d E_{i}
\end{aligned}
$$

によって定義される拡張コンプリメンタリー・エネル ギ一密度, その力学的寄与分, 電気的寄与分である. ま た, $\sigma_{i j}, \varepsilon_{i j}, u_{i}, T_{i}$ はそれぞれ忘力, ひずみ, 変位, 表面 力, $D_{i}, E_{i}, \phi, q_{s}$ はそれぞれ電気変位, 電界, 電位, 表面 電渮であり, 0 から $t$ の積分は初期状態の時刻 0 から現 在の時刻 $t$ まで実際の履歷に沿って行うことを意味す る. さらに $\Gamma_{0}, \Gamma$ はそれぞれ切久き端の半円状の径路, 切欠きを囲む任意の径路, $A$ は $\Gamma_{u}, \Gamma_{d}$ をそれぞれ切欠 き上面,下面の径路として閉曲線 $\Gamma+\Gamma_{u}-\Gamma_{0}+\Gamma_{d}$ によ って曲まれる領域の面積であり, $n_{i}$ はこの閉曲線上の 外向き単位法線べクトルである. 式(1)-(6)において, 最 初の等号で結ばれた関係がそれぞれ各量の定義を与え るもので, き裂端が担う各エネルギ一あるいは各コン プリメンタリー・エネルギーのき裂直進方向面内での 面積密度の意味を持つものとなっており, 最右辺はそ れらの径路独立積分表示となっている.

さらに関連する量として, $H$ を

$$
H=W^{M}-W_{c}^{E}
$$

によって定義される量として, 式(2), (6)より, $H$ の面積 密度の意味を持つ $\mathcal{E}^{H}$ の定義式およびその径路独立積 分表示が次のように与えられる.

$$
\begin{aligned}
\mathcal{E}^{H} & =\mathcal{E}^{M}-\mathcal{E}_{c}^{E}=\int_{\Gamma_{0}} H d X_{2} \\
& =\int_{\Gamma}\left(H n_{1}-T_{i} u_{i .1}+q_{s} \phi_{, 1}\right) d \Gamma
\end{aligned}
$$

ここで,式(2),(6)の径路独立積分表示には $A$ に関する面 積分が存在するが, 可逆な挙動においては

$$
\sigma_{i j, 1} d \varepsilon_{i j}-\varepsilon_{i j, 1} d \sigma_{i j}+E_{i, 1} d D_{i}-D_{i, 1} d E_{i}=0
$$

が成り立つので(1), 式(10)では面積分が消去されること になる.この間の事情は, 式(2),(3) の和である式(1)にお いて, また, 式(5), (6) の和である式(4)において面積分が 現れないのと同様である. 圧電体の構成則は応力, ひず み, 電界, 電気変位の間の関係として与えられ, 温度や エントロピーの影響は小さいとしてそれらは無視した 形で扱われるのが普通である.このとき, $W$ や $W_{c}$ は状 態量と見なせるので, 式(1), (4), (10)の $\mathcal{E}, \mathcal{E}_{c}, \mathcal{E}^{H}$ は現 在の状態のみで定まる量となり, 上述の面積分が消去 
されることに対応する. しかし,$W や W_{c}$ を分離した $W^{M}, W^{E}$ および $W_{c}^{M}, W_{c}^{E}$ は状態量ではないのでこれ らに対応する $\mathcal{E}^{M}, \mathcal{E}^{E}$ および $\varepsilon_{c}^{M}, \mathcal{E}_{c}^{E}$ は履歷に依存し， 式(2),(3)および式(5), (6)には面積分項が存在することに なる. $H$ は等温過程において電気エンタルピー密度の 意味を持つ量であるが, 温度やエントロピーについて 考えないとき, やはり電気エンタルピー密度と呼んで よいであろう. 従って,このとき $\mathcal{E}^{H}$ は電気エンタルピ 一面積密度の意味を持つ量となる.

以上はき裂を切欠きでモデル化する場合に対する結 果であるが, 通常用いられる鋭いき裂モデルに対する 量は $\rho \rightarrow 0$ の極限として与えられるものを考えれば よく, CED およびその力学的寄与分, 電気的寄与分に ついて具体的に与えると

$$
\begin{aligned}
& \mathcal{E}^{(c)}=\lim _{p \rightarrow 0} \mathcal{E}=\lim _{p \rightarrow 0} \int_{\Gamma_{0}} W d X_{2} \\
& \mathcal{E}^{M(c)}=\lim _{p \rightarrow 0} \mathcal{E}^{M}=\lim _{p \rightarrow 0} \int_{\Gamma_{0}} W^{M} d X_{2} \\
& \mathcal{E}^{E(c)}=\lim _{p \rightarrow 0} \mathcal{E}^{E}=\lim _{p \rightarrow 0} \int_{\Gamma_{0}} W^{E} d X_{2}
\end{aligned}
$$

である.ここで上付きの $(c)$ は鋭いき裂に対する量で あることを示すものであり, 以後同様に用いる.なお式 (10)最右辺は, 形において, 鋭いき裂を対象に得られて いる圧電材料の $J$ 積分以の定義式と同じであるので

$$
\begin{aligned}
\mathcal{E}^{H(c)} & =\lim _{p \rightarrow 0} \int_{\Gamma_{0}} H d X_{2} \\
& =\lim _{\rho \rightarrow 0} \int_{\Gamma}\left(H n_{1}-T_{i} u_{i .1}+q_{s} \phi_{.1}\right) d \Gamma \\
& =\int_{\Gamma}\left(H n_{1}-T_{i} u_{i, 1}+q_{s} \phi_{.1}\right)^{(c)} d \Gamma=J
\end{aligned}
$$

なる関係が成り立ち, 圧電材料の $J$ 積分は鋭いき裂に 対する電気エンタルピー面積密度の意味を持つ。

\section{3. エネルギ一解放率の導出とCED等との関係}

$3 \cdot 1$ エネルギ一解放率の導出 通常の材料に おいては, 弾性問題であれば,もちろんそれらの意味は 異なるが,エネルギ一解放率は值において CEDに等し くなることが示されている(1)ここでは,構成則が応力, ひずみ, 電界, 電気変位の間の可逆な関係として与えら れる圧電体を考え, そのエネルギ一解放率を導き, 前章 にまとめた CED および CED 関連量との関係を明ら かにしてその意味を明確にする.なおここでも,簡単の ため,体積力と体積電荷の存在は考えないものとする.

図 2 に切欠き状き裂端近傍の様子のみを示寸が, 外 境界で力学的, 電気的外力を受けている圧電体におけ る切欠き状き裂の進展を考え, 鋭いき裂に対する諸量 は,ここでも, 得られる結果の $\rho \rightarrow 0$ における極限とし

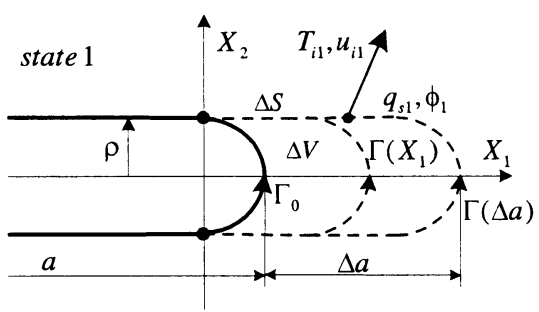

(a) Before extension

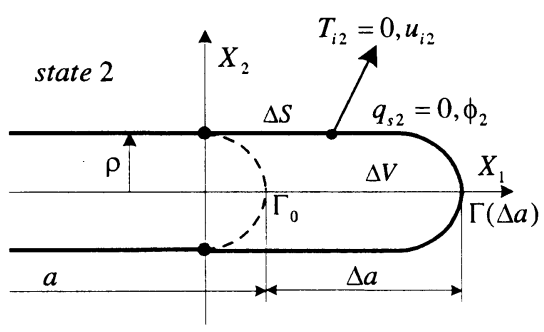

(b) After extension

Fig. 2 Crack extension

て与える.き裂進展前の圧電体の体積を $V$ として,切欠 き状き裂の進展は, 図 2(a)のき裂進展直前の状態 状態 1 ; 時刻 $t_{1}$ 加ら, 進展量 $\Delta a$ に対応する切欠き端前方の 体積 $\Delta V$ を取り去り,この結果現れる新表面 $\Delta S$ 上の 表面力をゼ口, さらに本研究では切欠き面で不浸透性 条件を考えるので, 表面電荷についてもそれをゼロに することによって実現され，図 2(b)の状態 (状態 2 ; 時 刻 ち) になる.この変化の間,一般的には外境界での力 学的, 電気的外力も仕事をするのでこの外力仕事を $\Delta L$ とするとき,き裂の進展に伴って解放されるエネ ルギー $-\Delta E$ は

$$
-\Delta E=\Delta L-\left(U_{2}-U_{1}\right)
$$

となる.ここで $U$ は压電体全体の拉張ひずみエネルギ 一であり，下付き 1,2 はそれぞれ状態 1 , 状態 2 に対す る量であることを表し,以後同様に用いる. 状態 1,2 に 対する全拡張ひずみエネルギーの差は

$$
\begin{aligned}
-\Delta U & =U_{1}-U_{2}=\int_{V} W_{1} d V-\int_{V-\Delta V} W_{2} d V \\
& =\int_{\Delta V} W_{1} d V-\int_{V-\Delta V}\left(W_{2}-W_{1}\right) d V
\end{aligned}
$$

と表せる. そしてこの式の最右辺の第 1 項および第 2 項の負号を除いた量は，それぞれ，外力を受けていない 初期の状態状態 0 ; 時刻 0$)$ から状態 1 また, 状態 1 か ら状態 2 の間に, それぞれ, $\Delta V, V-\Delta V$ 部分にそれら の境界面を介して力学的, 電気的になされる仕事に等 
しいことを考えると, 式(15)の全拡張ひずみエネルギ 一の差は,さらに

$$
\begin{aligned}
-\Delta U= & -\int_{\Delta S} \int_{0}^{t_{1}}\left(T_{i}^{\Delta v} d u_{i}+\phi d q_{s}^{\Delta V}\right) d S \\
& -\left\{\int_{\Delta S} \int_{t_{1}}^{t_{2}}\left(T_{i}^{V-\Delta v} d u_{i}+\phi d q_{s}^{V-\Delta v}\right) d S+\Delta L\right\}
\end{aligned}
$$

と表せる.ここで,上付き $\Delta V, V-\Delta V$ は,それぞれ $\Delta S$ 上で, 体積 $\Delta V$ 側に作用するものであるか, あるいは， 体積 $V-\Delta V$ 側に作用するものであるかを区別するた めに付したものであり, また, 式(16)の第 1 項に負号が 付くのは, 体積 $V-\Delta V$ の境界面での外向き単位法線 ベクトルを考えていることからくる. 式(16)を式(14)に 適用すると

$$
\begin{aligned}
-\Delta E= & -\int_{\Delta S} \int_{0}^{t_{1}}\left(T_{i}^{\Delta V} d u_{i}+\phi d q_{s}^{\Delta V}\right) d S \\
& -\int_{\Delta S} \int_{t_{1}}^{t_{2}}\left(T_{i}^{V-\Delta V} d u_{i}+\phi d q_{s}^{V-\Delta V}\right) d S
\end{aligned}
$$

となり, 結果として, き裂の進展により解放されるエネ ルギーに外力仕事は関係しなくなる.

ここで式(17)の各項の意味を明確にするため図で考 えてみよう.図 $3(\mathrm{a}),(\mathrm{b})$ は，それぞれ，図 2 において $\Delta S$ の $X_{2} \geq 0$ の部分上の表面力と変位および 電位と電荷 の間の関係を,簡単のため, 圧電体は線形挙動をするも のとして模式的に描き, き裂進展に伴う力学的エネル ギー,電気的エネルギーの変化を示したものである. 一 般性は失われないので, き裂端の $\left(X_{1}, X_{2}\right)=(\rho, 0)$ 点で の変位と回転および電位をゼロとする支持条件の下, 当該位置の応力, ひずみ, 電界, 電気変位が正となるよ うな外力の下での関係を考えている. 図(a)においては, $u_{i}$ 軸を挟んで上側は $\Delta V$ から見た, 下側はV $-\Delta V$ か ら見た，また図(b)においては， $\phi$ 軸を挟んで左側は $\Delta V$ ． から見た, 右側は $V-\Delta V$ から見た挙動を示しており, 何れの図においても, $O$ 点は状態 0 に, $C, C^{\prime}$ 点はそれ ぞれ $\Delta V, V-\Delta V$ から見た状態 1 に, D 点は $V-\Delta V$ から見た状態 2 に, $\mathrm{O}^{\prime}$ 点は $\mathrm{O}$ 点に一致する点である が, $\Delta V$ から見た状態 2 に対応する. $C, C^{\prime}$ 点は同じ位 置の表面力あるいは電荷を $\Delta V$ から見たか, $V-\Delta V$ から見たかの違いであるので, 図(a)では $u_{i}$ 軸に関し， 図(b)では $\phi$ 軸に関し対称の位置にある点であり,その 意味は次に説明されるが, $\mathrm{A}, \mathrm{A}^{\prime}$ 点, $\mathrm{B}, \mathrm{B}^{\prime}$ 点について も同様である. 先に論じたように(17, 初期の状態 0 から 外力を受けてき裂進展直前の状態 1 に至る変化, いま の場合, O からCあるいはO からC'への変化はたと え線形挙動をする場合であっても外力の履歷に依存す る.すなわち, 線形挙動をする場合, 例えば, 力学的外力 と電気的外力が一定の割合を保ちつつ加えられる比例

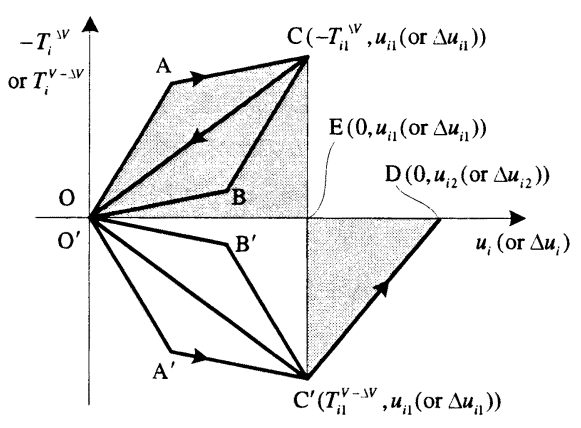

(a) Relation between traction force and displacement

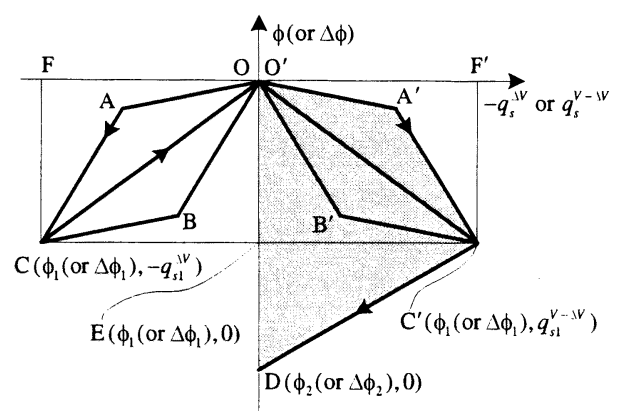

(b) Relation between electric potential and surface charge

Fig. 3 Energy variation with crack extension

負荷の場合を考えると, 図中O からC ( $\left.\mathrm{C}^{\prime}\right)$ に直線状 に変化するが, 力学的外力を加え終わってから電気的 外力を加える, あるいは逆に, 電気的外力を加え終わっ てから力学的外力を加える場合を考えると，それぞれ， $\mathrm{O}-\mathrm{A}-\mathrm{C}\left(\mathrm{O}-\mathrm{A}^{\prime}-\mathrm{C}^{\prime}\right), \mathrm{O}-\mathrm{B}-\mathrm{C}\left(\mathrm{O}-\mathrm{B}^{\prime}-\mathrm{C}^{\prime}\right)$ と二 直線で表される変化をするというように, $C\left(C^{\prime}\right)$ 点 の位置は変わらないがそれに至る径路は履歴に依存す る.ここで力学的外力のみ, あるいは, 電気的外力のみ を増しているときの直線的変化の傾きはそれぞれ一定 であるべきなので, 四辺形 $\mathrm{OACB}, \mathrm{OA}^{\prime} \mathrm{C}^{\prime} \mathrm{B}^{\prime}$ は平行四 辺形である. またC 点に至るまでに $\Delta V$ 部分になされ る全仕事は状態 1 の状態のみで定まり, それに至る径 路に依存するものではないので, 常に図(a)の三角形 OCE と図(b)の三角形 OCF の面積の和として与えら れる性質のものであり, 従って, 図(a), (b)の三角形 $\mathrm{OAC}(\mathrm{OBC})$ の面積は等しくなり,$V-\Delta V$ から見て も同様で, 図(a), (b)の三角形 $\mathrm{OA}^{\prime} \mathrm{C}^{\prime}\left(O \mathrm{~B}^{\prime} \mathrm{C}^{\prime}\right)$ )面積は等 しくなる.

次に状態 1 から状態 2 へのき裂進展に伴う変化であ るが, 進展に伴って $\Delta S$ が自由表面になることによる $\Delta S$ 上での力学的, 電気的外力の除荷は $\Delta V, V-\Delta V$ 何れの側でも比例的に起こると考えるのが自然である 
ので, $\Delta V$ の側では図上Cからの'の直線変化で表され, $V-\Delta V$ の側では $\mathrm{C}^{\prime}$ から D へのはり直線変化で示 されることになる. こうして, いま, 先ず力学的外力が 加わってから電気的外力が加わる場合を例にして考え ると,状態 0 から状態 1 を経て状態 2 に至る变化は, 図 中矢印で示すように, $\Delta V$ 側では $\mathrm{O}-\mathrm{A}-\mathrm{C}-\mathrm{O}^{\prime}$, $V-\Delta V$ 側ではO $-\mathrm{A}^{\prime}-\mathrm{C}^{\prime}-\mathrm{D}$ で表される. 従って, 各 項についている負号も含めて考えて, 式(17)第 1 項中の 第 1 項が図(a)の面積OACE に第 2 項が図(b)の面積 $\mathrm{OACF}$ に対応し，また，第 2 項中の第 1 項が図(a)の面 積C'DEに第 2 項についてはその絶対值が図(b)の面積 $\mathrm{C}^{\prime} \mathrm{DOF}^{\prime}$ に対応する. 結局, き裂進展に伴って解放され るエネルギーは, 図(a)の薄墨を施した部分の面積から 図(b)の薄墨を施した部分の面積を引いたものが対応す ることが分かる.なお圧電体が非線形挙動をする場合 であっても, その場合は図上の直線が曲線状となり, ま た, 解の一意性が保証されないので, $\mathrm{C}\left(\mathrm{C}^{\prime}\right)$ 点やD , $\mathrm{O}^{\prime}$ 点の位置が履歷に依存する $\left(O^{\prime}\right.$ 点は $O$ 点に一致しな い)といったことも考えられるが, 上述と同じ解放され るエネルギーと図上の面積との対応が成り立つことは 明らかである.

さて以後厚さ方向については単位厚さあたりを考え ることにしよう.このとき式(17)右辺の $\Delta S$ 上の積分は， 第 1 項と第 2 項共, 次のように分解することができる.

$-\int_{\Delta S}\left(T_{i} d u_{i}+\phi d q_{s}\right) d S=-\left\{\int_{0}^{\Delta u}\left(T_{i} d u_{i}+\phi d q_{s}\right)^{d} d X_{1}\right.$

$\left.+\int_{\Gamma(\Delta, i)}\left(T_{i} d u_{i}+\phi d q_{s}\right) d \Gamma+\int_{\Lambda_{u}}^{0}\left(T_{i} d u_{i}+\phi d q_{s}\right)^{u}\left(-d X_{1}\right)\right\}$

ここで上付きの $u, d$ は, 図 2 において, それぞれ, 面 $\Delta S$ の $X_{1}$ 軸に平行な部分の上と下に対するものであ ることを意味しており，以後同椂に用いる.

i）エネルギ一解放率 1 ここで $\Delta a \rightarrow 0$ とす る場合を考える.このとき式(18)における上下面での寄 与は消え,その右辺は

$-\int_{\Delta S}\left(T_{i} d u_{i}+\phi d q_{s}\right) d S=-\int_{\Gamma(\Delta \Delta)}\left(T_{i} d u_{i}+\phi d q_{s}\right) d \Gamma$

となる. $\Delta V$ の右端の径路 $\Gamma(\Delta a)$ が限りなく切欠き状 き裂の自由表面径路 $\Gamma_{0} に$ に近づくことを念頭に，図 3 を 参照しつつ, 式(17)の右辺における各項のオーダーを比 較することを考える.このとき，まず第 1 項は， $-T_{i 1}^{\Delta V}\left(=-T_{i 1}^{V-\Delta V}\right) \rightarrow 0,-q_{s 1}^{\Delta V}\left(=-q_{s 1}^{V-\Delta V}\right) \rightarrow 0$ である が $u_{i 1}, \phi_{1}$ は有限であるので一次の微小量となる.一方, $T_{i 2}^{V-\Delta V}(=0)-T_{i 1}^{V-\Delta V} \rightarrow 0$ となることから, $u_{i 2}-u_{i 1}$ $\rightarrow 0$ であり, 第 2 項中第 1 項は二次の微小量, しかし, 第 2 項は $q_{s 2}^{V-\Delta V}(=0)-q_{s 1}^{V-\Delta V} \rightarrow 0$ となって $\phi_{2}-\phi_{1}$ $\rightarrow 0$ であるが, $\phi_{1}$ は有限であるので, 一次の微小量と なる(図 3(b)参照).従って,式(17)は

$$
\begin{aligned}
-\Delta E= & -\int_{\Delta S} \int_{0}^{t_{1}}\left(T_{i}^{\Delta V} d u_{i}+\phi d q_{s}^{\Delta V}\right) d S \\
& -\int_{\Delta S} \int_{t_{1}}^{t_{2}}\left(\phi d q_{s}^{V-\Delta V}\right) d S
\end{aligned}
$$

となり, 図 3(b)中三角形C'DE の面積は二次の微小量, 長方形 OEC'F' $\mathrm{F}^{\prime}$ の面積は長方形OECF の面積に等し いことも考慮すると,式(20)の関倸は

$$
\begin{aligned}
-\Delta E & =\int_{\Delta V} W_{1} d V-\int_{\Delta V}\left(W_{1}^{E}+W_{c 1}^{E}\right) d V \\
& =\int_{\Delta V}\left(W_{1}^{M}-W_{c 1}^{E}\right) d V
\end{aligned}
$$

と表せ，さらに $\Gamma\left(X_{1}\right)$ を図 2(a)に示すき裂端前方の $\Gamma_{0}$ と同一形状の径路とすると

$$
\begin{aligned}
-\Delta E & =\int_{0}^{\Delta a}\left[\int_{\Gamma\left(X_{1}\right)}\left\{W_{1}-\left(W_{1}^{E}+W_{c 1}^{E}\right)\right\} d X_{2}\right] d X_{1} \\
& =\int_{0}^{\Delta a}\left\{\int_{\Gamma\left(X_{1}\right)}\left(W_{1}^{M}-W_{c 1}^{E}\right) d X_{2}\right\} d X_{1}
\end{aligned}
$$

とも表現できる.こうして,き裂が進展するときのエネ ルギ一解放率 $\mathcal{G}$ は式(1), (2), (3), (6), (10), また $W$ におけ る下付き 1 による区別は不要となることも考慮して

$$
\begin{aligned}
\mathcal{G} & =\lim _{\Delta a \rightarrow 0}\left(-\frac{\Delta E}{\Delta a}\right)=\int_{\Gamma_{0}}\left\{W-\left(W^{E}+W_{c}^{E}\right)\right\} d X_{2} \\
& =\int_{\Gamma_{0}}\left(W^{M}-W_{c}^{E}\right) d X_{2}=\mathcal{E}-\left(\mathcal{E}^{E}+\mathcal{E}_{c}^{E}\right) \\
& =\mathcal{E}^{M}-\mathcal{E}_{c}^{E}=\mathcal{E}^{H}
\end{aligned}
$$

と得られる.

鋭いき裂を考える場合には $\rho \rightarrow 0$ とした極限を考 えればよく,式(13)も考慮して

$$
\begin{aligned}
\mathcal{G}_{1}^{(c)} & =\lim _{p \rightarrow 0} \mathcal{G}=\mathcal{E}^{(c)}-\left(\mathcal{E}^{E(c)}+\mathcal{E}_{c}^{E(c)}\right) \\
& =\mathcal{E}^{M(c)}-\mathcal{E}_{c}^{E(c)}=\mathcal{E}^{H(c)}=J
\end{aligned}
$$

と得られこれまでいわれているJ 積分はエネルギー 解放率に等しいという結果に一致する. なお $\rho \rightarrow 0$ に おいてき裂端 $\Gamma_{0}$ は一点に近づくのであるから，極限に おいてき裂進展に際し体積を取り去ることとならない のはいうまでもなく, 極限においても有限な值をとる 面積密度の形でそこに蓄えられていたエネルギーのみ が,すなわち, $\mathcal{E}^{(c)}$ のみが取り去られることになる.

ii ）エネルギ一解放事 2 i )においては鋭いき 裂のエネルギ一解放率を導くにあたり，式(17)において， $\Delta a \rightarrow 0$ とした後に $\rho \rightarrow 0$ という操作を行ったが, こ こでは, 逆に $\rho \rightarrow 0$ とした後に $\Delta a \rightarrow 0$ とする場合を 
考えて見る. 面 $\Delta S$ の $X_{1}$ 軸に平行な部分上の $X_{1}$ が等 しい上下の位置の相対変位 $\Delta u_{i}=u_{i}^{u}-u_{i}^{d}$, 電位差 $\Delta \phi=\phi^{u}-\phi^{d}$ を考え, 図中括弧内に示すように, 図 $3(\mathrm{a})$ で $u_{i}$ を $\Delta u_{i}$, 図3(b)で $\phi$ を $\Delta \phi$ に置き換えるとき, これ らの図は, 状態 0 から状態 2 まで変化する間の, 上面当 該位置の表面力と相対変位, 電位差と上面当該位置の 表面電荷の間の関係を示していると見ることもできる. $\rho \rightarrow 0$ とするとき,式(18)において右辺の第 2 項の寄与 は消え, さらに $T_{i}^{u}+T_{i}^{d} \rightarrow 0, d q_{s}^{u}+d q_{s}^{d} \rightarrow 0$ であるこ とを用いると

$-\int_{\Delta s}\left(T_{i} d u_{i}+\phi d q_{s}\right) d S$

$=-\int_{0}^{\Delta a}\left[\left\{\left(T_{i} d u_{i}\right)^{u}+\left(T_{i} d u_{i}\right)^{d}\right\}+\left\{\left(\phi d q_{s}\right)^{u}+\left(\phi d q_{s}\right)^{d}\right\}\right] d X_{1}$

$=-\int_{0}^{\Delta a}\left\{T_{i}^{u} d\left(\Delta u_{i}\right)+\Delta \phi d q_{s}^{d}\right\} d X_{1}$

となる.従って, 図 3 で括弧内の $\Delta u_{i}, \Delta \phi$ を用いるとき, 図中の各面積は, $\rho \rightarrow 0$ においては, 対応寸る 2 点を一 対のものとして, 先の議論と同じ意味を持つものとな るので, 図を参照しつつ $\rho \rightarrow 0$ とするときの式(17)の各 項のオーダーを比較する.

すなわち $\rho \rightarrow 0$ とするとき, $-T_{i 1}^{\Delta V}\left(=-T_{i 1}^{V-\Delta V}\right) \rightarrow \infty$, $\Delta u_{i 1} \rightarrow 0$, また, $-q_{s 1}^{\Delta V}\left(=-q_{s 1}^{V-\Delta V}\right) \rightarrow-\infty, \Delta \phi_{1} \rightarrow 0$ で あるので, 第 1 項目は $\infty \times 0$ のオーダーである. 一方, $T_{i 2}^{V-\Delta V}(=0)-T_{i 1}^{V-\Delta V} \rightarrow \infty, \Delta u_{i 2}-\Delta u_{i 1}(\rightarrow 0) \rightarrow$ 有限值, また, $q_{s 2}^{V-\Delta V}(=0)-q_{s 1}^{V-\Delta V} \rightarrow-\infty, \Delta \phi_{2}-\Delta \phi_{1}(\rightarrow 0) \rightarrow$ (負の) 有限值であるので, 第 2 項目は $\infty \times$ 有限值のオ ーダーとなる. 従って第 2 項目のみを考えればよいこ とになり,式(25)も考慮し, 以後式中 $V-\Delta V$ は省略する が, $V-\Delta V$ 側から見た表面力, 表面電荷を用いるもの として,式(17)の関係は

$$
-\Delta E=-\int_{0}^{\Delta a} \int_{i_{1}}^{t_{2}}\left(T_{i}^{u} d\left(\Delta u_{i}\right)+\Delta \phi d q_{s}^{u}\right) d X_{1}
$$

で与えられ，さらにこれは $T_{i}^{u}=\sigma_{i j}^{u} n_{j}^{u}=-\sigma_{i 2}^{u}$, $q_{s}^{u}=-D_{i}^{u} n_{i}^{u}=D_{2}^{u}\left(n_{1}=0, n_{2}=-1\right)$ であること(ここ での下付き 2 はテンソル指標の值が 2 であることを意 味する), また $\rho \rightarrow 0$ においては $\sigma_{i 2}^{u}=\sigma_{i 2}^{d}, D_{2}^{u}=D_{2}^{d}$ と なって $u, d$ を付けしての区別は不要となることも考 慮して

$$
-\Delta E=\int_{0}^{\Delta a} \int_{t_{1}}^{t_{2}}\left\{\sigma_{i 2} d\left(\Delta u_{i}\right)-\Delta \phi d D_{2}\right\} d X_{1}
$$

とも表現される.特に線形問題の場合には，図 3(b)にお いて $\rho \rightarrow 0$ のとき $\mathrm{C}^{\prime}$ 点は $\mathrm{F}^{\prime}$ 点に一致して $q_{s}^{v-\Delta V}$ 軸上 の点となり, 状態 1 から状態 2 一の変化は $C^{\prime}$ 点から
$\mathrm{D}$ 点への直線変化で表されるので, 上式は, 状態 1 での $D_{2}$ は正であるが, この変化に沿っての $d D_{2}$ は負とな ることも考慮して

$$
\begin{aligned}
-\Delta E=\frac{1}{2} \int_{0}^{\Delta a}\left\{\sigma_{i 2}\left(X_{1}\right) \Delta u_{i}\left(\Delta a-X_{1}\right)\right. \\
\left.+\Delta \phi\left(\Delta a-X_{1}\right) D_{2}\left(X_{1}\right)\right\} d X_{1}
\end{aligned}
$$

と書ける.ただし, $\sigma_{i 2}\left(X_{1}\right), D_{2}\left(X_{1}\right)$ は, それぞれ, 状態 1 におけるき裂端前方の応力, 電気変位の分布であり, $\Delta u_{i}\left(\Delta a-X_{1}\right), \Delta \phi\left(\Delta a-X_{1}\right)$ は, それぞれ, 状態 2 にお けるき裂端後方き裂面上下の相対変位,電位差である. エネルギー解放率は

$$
\mathcal{G}_{\text {ii) }}^{(c)}=\lim _{\Delta a \rightarrow 0}\left(-\frac{\Delta E}{\Delta a}\right)
$$

に式(27)を代入することにより,特に線形問題の場合に は式(28)を代入することによっても求まり，後者は従来 圧電体のエネルギ一解放率として具体的に論じられて いるものとなる.

3.2 考察 エネルギー解放率は「き裂端の一点 が開くことにより解放されるエネルギーを単位面積あ たりで表したもの」と定義されるが,このエネルギー 解放率として $\mathcal{G}_{\mathrm{i}}^{(c)}\left(\right.$ 式(24)) と $\mathcal{G}_{\mathrm{i} i)}^{(c)}($ 式(29))の 2 通りのも のが導かれた.まず式(24)の関係であるが,これは, エネ ルギ一解放率が, き裂を含む面内のき裂端の一点に蓄 えられ，その一点が開くことにより解放されるエネル ギーに転じるエネルギ一面積密度の意味を持つ $\mathcal{E}^{(c)}$ と， それに負号を付したものが進展前のき裂端の一点に存 在していた $\mathcal{E}^{E(c)}+\mathcal{E}_{c}^{E(c)}$ の值に等しい, き裂端の一点 が開くことにより生じる新たなき裂端を電気的自由表 面にするために解放される電気的エネルギーを単位面 積あたりで表したものとの和として与えられることを 意味している.そしてそれがさらに, 值において進展前 のき裂端の一点における $\mathcal{E}^{M(c)}$ と $\mathcal{E}_{c}^{E(c)}$ の差,すなわち, $\mathcal{E}^{H(c)}$, ひいて $J$ に等しいということを示している. $\mathcal{E}^{H(c)}$ の意味はあくまで電気エンタルピー面積密度で あって, その值にエネルギ一解放率の值は等しいとい うことであり,$J$ 積分とエネルギ一解放率の関係につ いてもそのように捉えるのが正確であろうと思われる. 一方 $\mathcal{G}_{\mathrm{i})}^{(c)}$ は, 式(27)を見れば分かるように, き裂端の 一点が開いたとき新たに生じる新表面を自由表面にす るために力学的および電気的に解放されるエネルギー をそれぞれ単位面積あたりで表したものの和となって おり, 通常のエネルギ一解放率の考え方に一致する. そ してこれまで行われているようにゅ,それらをそれぞれ 力学的エネルギ一解放率 $\mathcal{G}_{\mathrm{i} i}^{M(c)}$, 電気的エネルギ一解 


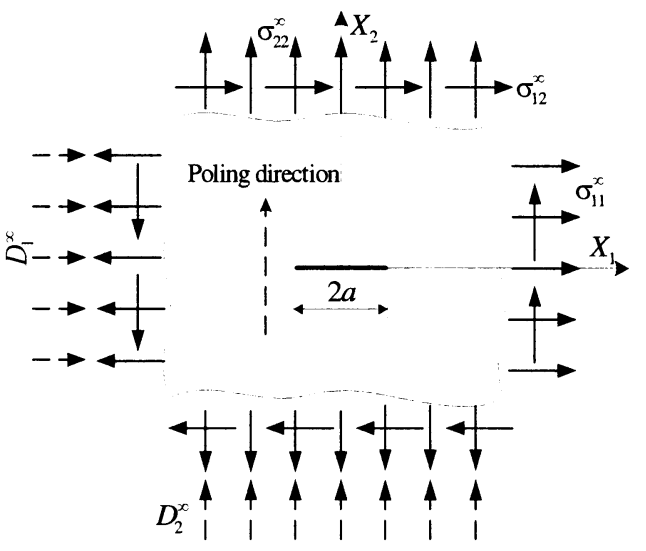

Fig. 4 Piezoelectric infinite medium with a central crack under electro-mechanical loadings

放率 $\mathcal{G}_{\mathrm{ii})}^{E(c)}$ とすることができ, き裂端周りの特異場の 解が与えられる線形問題の場合には, 式(28), (29)にそ の特異解を適用することによりこれらのエネルギ一解 放率を具体的に与えることができる.ここでは例とし て図 4 に示すような $X_{2}$ 軸に分極方向が一致し, き裂 面が直交する圧電無限板が, 無限䞦で力学的負荷と電 気的負荷 $\left(\sigma_{11}^{\infty}, \sigma_{22}^{\infty}, \sigma_{12}^{\infty}, D_{1}^{\infty}, D_{2}^{\infty}\right)$ を同時に受ける 場合を考える. このとき, Sosaによる特異場の解をを用 いることにより

$$
\begin{aligned}
& \mathcal{G}_{\mathrm{ii})}^{M(c)}=\frac{\pi a}{2}\left\{-\operatorname{Im} \sum_{k=1}^{3} q_{k} \Lambda_{k 1}\left(\sigma_{22}^{\times}\right)^{2}+\operatorname{Im} \sum_{k=1}^{3} p_{k} \Lambda_{k 2}\left(\sigma_{12}^{\times}\right)^{2}\right. \\
& +\operatorname{Im} \sum_{k=1}^{3}\left(q_{k} \Lambda_{k 2}-p_{k} \Lambda_{k 1}\right) \sigma_{22}^{\times} \sigma_{12}^{\times}+\operatorname{Im} \sum_{k=1}^{3} p_{k} \Lambda_{k 3} \sigma_{12}^{\times} D_{2}^{\times} \\
& \left.+\operatorname{Im} \sum_{k=1}^{3} q_{k} \Lambda_{k 3} \sigma_{22}^{\times} D_{2}^{\times}\right\}
\end{aligned}
$$

$\mathcal{G}_{\mathrm{ii})}^{E(c)}=\frac{\pi a}{2}\left\{\operatorname{Im} \sum_{k=1}^{3} r_{k} \Lambda_{k 1} \sigma_{22}^{x} D_{2}^{x}-\operatorname{Im} \sum_{k=1}^{3} r_{k} \Lambda_{k 2} \sigma_{12}^{x} D_{2}^{x}\right.$

$\left.-\operatorname{Im} \sum_{k=1}^{3} r_{k} \Lambda_{k 3}\left(D_{2}^{x}\right)^{2}\right\}$

となり， $\mathcal{G}_{\mathrm{ii})}^{(c)}$ がこれらの和であることはいうまでも ない.ここで, 式中心定数 $q_{k}, p_{k}, r_{k}, \Lambda_{k i}$ 等はすべて材 料定数の関数であり, その具体的な表現については文 献(2)を参照されたい!

さてここで, $2 つ$ つネルギ一解放率 $\mathcal{G}_{1)}^{(c)}, \mathcal{G}_{\mathrm{ii})}^{(c)}$ が一 致するのか, $G_{\mathrm{ii}}^{(c)}$ は力学的寄与分と電気的寄与分に分 けられたが, $G_{1}^{(c)}$ についてはどうかといったことを考 えてみよう. 先ず両者が一致するかということである が, 式(13)において，その径路独立性から「としてき裂 端に近い円状の径路を選択し, 特異解を適用すること により, $\mathcal{E}^{H(c)}$ ( $J$ 積分) を求めることができる. 再び
Sosa の解を適用して調べたところ,この場合は $G_{\text {ii })}^{(c)}$ の ように閉じた形での表現は与えにくいが, MATHEMATICA を用いることにより,数值的に $\mathcal{E}^{H(c)}$ $\left(J\right.$ 積分) が $G_{\mathrm{i})}^{(c)}$ に一致することが確認された. 2 つの エネルギ一解放率は一般に線形問題であれば一致する ものと思われ, 非線形問題においても, 線形問題のよう な直接的証明は困難であるが, 両者は一致する,すなわ ち

$$
\mathcal{G}_{\mathrm{i})}^{(c)}=\left(\mathcal{E}^{H(c)}=J\right)=\mathcal{G}_{\mathrm{ii})}^{(c)}=\mathcal{G}_{\mathrm{ii})}^{M(c)}+\mathcal{G}_{\mathrm{ii})}^{E(c)}
$$

が成り立つものと考えてよいであろう.

次に $\mathcal{G}_{i)}^{(c)}$ の力学的寄与分と電気的寄与分八の分離 についてであるが，一見式(24)において $\mathcal{E}^{M(c)}$ と $-\mathcal{E}^{E(c)}$ がそれらに対応するように見えるが, $\mathcal{E}^{H(c)}$ とは異な ってこれらは履歴に依存する量であり, 意味はもちろ ん, 数值的にも $\mathcal{G}_{\mathrm{ii})}^{M(c)}, \mathcal{G}_{\mathrm{ii})}^{E(c)}$ と異なることは明らかで ある.ここで「はき裂端を囲む任意の径路であるから， その径路として部分的に $\Gamma(\Delta a)$ を含む図 $2(\mathrm{a})$ の $\Delta S$ に 沿った径路 $\Gamma_{\rho}$ を考えて $\rho \rightarrow 0$ とするとき, $\Gamma(\Delta a)$ 部 分の寄与はなくなり, 他の部分では $n_{1}=0$ であるので, 式(10)より

$$
\begin{aligned}
\mathcal{E}^{H(c)} & =\mathcal{E}^{M(c)}-\mathcal{E}_{c}^{E(c)} \\
& =\lim _{\rho \rightarrow 0} \int_{\Gamma_{1}}\left(-T_{i} u_{i .1}\right) d \Gamma+\lim _{\rho \rightarrow 0} \int_{\Gamma_{p}}\left(q_{s} \phi_{.1}\right) d \Gamma
\end{aligned}
$$

なる関係が得られる. そして $\mathcal{E}^{M(c)},-\mathcal{E}^{E(c)}$ は履歴に依 存するが, 上式最右辺の第 1 項, 第 2 項はそれぞれ現在 の力学的量, 電気的量のみで定まり, 履歴には依存しな い量となっているので, それらをそれぞれ $\mathcal{G}_{1}^{M(c)}$, $\mathcal{G}_{1}{ }^{E(c)}$ で表し,$A_{p}$ を閉径路 $\Gamma_{p}-\Gamma_{0}$ で井まれる部分の 面積として,式(2),(6)も適用すると

$$
\begin{aligned}
\mathcal{G}_{i)}^{M(c)} & =\lim _{\rho \rightarrow 0} \int_{\Gamma_{i}}\left(-T_{i} u_{i, 1}\right) d \Gamma \\
& =\mathcal{E}^{M(c)}+\lim _{\rho \rightarrow 0} \int_{A_{p}} \int_{0}^{t}\left(\sigma_{i j, 1} d \varepsilon_{i j}-\varepsilon_{i j, 1} d \sigma_{i j}\right) d A \\
\mathcal{G}_{1}^{E(c)} & =\lim _{\rho \rightarrow 0} \int_{\Gamma_{\rho}}\left(q_{s} \phi_{, 1}\right) d \Gamma \\
& =-\mathcal{E}_{c}^{E(c)}+\lim _{\rho \rightarrow 0} \int_{A_{\rho}} \int_{0}^{t}\left(E_{j, 1} d D_{j}-D_{j, 1} d E_{i}\right) d A
\end{aligned}
$$

であり, これらが $G_{1}^{(c)}$ の力学的寄与分, 電気的寄与分を 与えるものとなる. 式(11)が成り立つので, これらの和 をとるとき面積分の寄与分が相殺されるのはもちろん であり,式(31)であることも考えると, $\mathcal{G}_{\mathrm{i})}^{M(c)}, \mathcal{G}_{\mathrm{i})}^{E(c)}$ はそ れぞれ $\mathcal{G}_{\mathrm{ii})}^{M(c)}, \mathcal{G}_{\mathrm{ii})}^{E(c)}$ に值において一致するものと思わ れる.

\section{4. 結言}


CED に関わる知識を踏まえて, き裂面電気的不浸透 条件の下での圧電体のエネルギ一解放率について論じ, CED やその関連量, $J$ 積分と呼ばれる量との関係等, エネルギー解放率に関わる基本的事項を明らかにした。 なお, 本論では触れなかったが, 圧電体のエネルギ一解 放率にはその電気的寄与分が負となる(き裂進展に伴 ってエネルギーを解放するのではなく逆に吸収する) といらエネルギー・バランスの議論には不都合な事実 がある(著者らは大切なのはCEDであり, エネルギ 一解放率は補助的なパラメータであると考えるもので あるが,この問題には電気的境界条件のあり方や微小 変形理論下の連続体力学モデル自体の問題が関わって くると思われるのでCED の観点からも重要であり,別 途改めて論じる予定である.

\section{文献}

(1) Pak, Y.E., Linear electroelastic fracture mechanics of piezoelectric materials, Journal of Applied Mechanics, Vol.112 (1992), pp.647-653.

(2) Sosa, H., On the fracture mechanics of piezoelectric solids, Int. J. Solids Struct, Vol.29 (1992), pp.2613-2622.

(3) Suo, Z. et al., Fracture mechanics for piezoelectric ceramics, J. Mech. Phys. Solids, Vol.35 (1992), pp.739765

(4) Park, S.B., Sun, C.T, Fracture criteria for piezoelectric ceramics, J. Am. Ceram. Soc, Vol.78 (1995), pp.14751480.

(5) Gao, H. et al., Local and global energy release rates for an electrically yielded crack in a piezoelectric œramic, $J$. Mech.Phys. Solids, Vol.45 (1997), pp.491-510.

(6) Fang, D.N. et al., Energy analysis on fracture of ferroelectric œramics, Int. J. Fract, Vol.100, No.4 (2000), pp.401-408.

(7) Shen, S., Nishioka, T., Fracture of piezoelectric material: energy density criterion, Theor. Appl. Fract. Mech, Vol.33 (2000), pp.57-65.

(8) Zuo, J.Z., Sih, G.C., Energy density theory formulation and interpretation of cracking behavior for piezoelectric ceramics, Theor. Appl. Fract. Mech, Vol.34 (2000), pp.17-33.

(9) Soh, AK et al., Fracture analysis of piezoelectric materials with defects using energy density theory, Int. J. Solids Struct, Vol.38 (2001), pp.8331-8344.

(10) McMeeking, RM., The energy release rate for a Griffith crack in a piezoelectric material, Eng. Fract. Mech, Vol.71 (2004), pp.1149-1163.

(11) Gao, C.F. et al., The energy release rate and the J integral of an electrically insulated crack in a piezoelectric material, Int. J. Eng. Sci, Vol.42 (2004), pp.2175-2192.

(12) Spyropoulos, C.P., Energy release rate and path independent integral study for piezoelectric material with crack, Int. J. Solids Struct, Vol.41 (2004), pp.907921.

(13) Watanabe, K, New proposal of crack energy density concept as a fundamental fracture mechanics parameter, Transactions of the Japan Society of Mechanical Engineers, Series A,Vol.47, No.416 (1981), pp.406-415.

(14) Watanabe, K, Crack energy density and energy release rate for elasto-plastic crack, Transactions of the Japan Society of Mechanical Engineers, Series A Vol.48, No.433 (1982), pp.1226-1236.

(15) Watanabe, $\mathrm{K}$, The conservation law related to path independent integral and expression of crack energy density by path independent integral, Transactions of the Japan Society of Mechanical Engineers, Series A, Vol.50, No.453 (1984), pp.894-903.

(16) Watanabe, K, Fatigue crack growth from the standpoint of crack energy density, Transactions of the Japan Society of Mechanical Engineers, Series A, Vol.51, No.463 (1985), pp.873-882.

(17) Nam, B.G., Watanabe, K, Crack energy density for piezoelectric body (Definition and derivation of fundamental relations), Transactions of the Japan Society of Mechanical Engineers, Series A, Vol.72, No.715 (2006), in printing. 